\title{
ANTIOXIDANT ACTIVITY OF ALKALOID FRACTIONS OF LITSEA CUBEBA LOUR. FRUITS
}

\author{
AMINAH DALIMUNTHE ${ }^{1 *}$, POPPY ANJELISA ZAITUN HASIBUAN ${ }^{1}$, JANSEN SILALAHI ${ }^{2}$, DENNY SATRIA ${ }^{3}$
}

${ }^{1}$ Department of Pharmacology, Faculty of Pharmacy, Universitas Sumatera Utara, Indonesia. ${ }^{2}$ Department of Pharmaceutical Chemistry, Faculty of Pharmacy, Universitas Sumatera Utara, Indonesia. ${ }^{3}$ Department of Pharmaceutical Biology, Faculty of Pharmacy, Universitas Sumatera Utara, Indonesia. Email: aminahdalimunthe@usu.ac.id

Received: 07 March 2018, Revised and Accepted: 25 March 2018

\section{ABSTRACT}

Objective: The oxidation induced by free radicals results in many degenerative disease. The purpose of this study is to determine antioxidant activities of alkaloid fractions of Litsea cubeba (Lour.) fruit.

Methods: L. cubeba Lour. was extracted by maceration. Ethanol extract was fractionated with liquid-liquid extraction using n-hexane and chloroform at $\mathrm{pH} 3,7,9$, and 11 to obtained alkaloid fractions. Antioxidant activity for extract and fractions was determined with 1,1-diphenyl-2-picrylhydrazyl.

Results: The $\mathrm{IC}_{50}$ of extract and fractions was $219.43 \pm 0.43,242.97 \pm 0.93,92.38 \pm 0.17,40.84 \pm 0.04,103.83 \pm 3.29$, and $103.75 \pm 0.42 \mu \mathrm{g} / \mathrm{mL}, \mathrm{respectively}$.

Conclusion: The results reveal that alkaloid fractions of $L$. cubeba fruits have very strong antioxidant potential. Our further study is to isolate the alkaloid compounds.

Keywords: Antioxidant, Litsea cubeba, Fruits, Alkaloid, Fractions.

(c) 2018 The Authors. Published by Innovare Academic Sciences Pvt Ltd. This is an open access article under the CC BY license (http://creativecommons. org/licenses/by/4. 0/) DOI: http://dx.doi.org/10.22159/ajpcr.2018.v11s1.26558

\section{INTRODUCTION}

Oxidation is an important process (normally) in living organisms. Free radicals are producing from metabolism pathway process or environmental sources which interact with biological system. Reactive species are molecules which have an electronic unstability and most reactive. Reactive oxygen species are the biggest sources of a primary catalyst which initiate the process of oxidation in vivo and in vitro and produce oxidative stress. Oxidative stress products when reactive forms of oxygen are produced faster than they could be safely neutralized with antioxidant mechanisms and/or from a decrease in antioxidant defense. The uncontrolled production of oxygen free radicals and the unrateable system of antioxidant capability in protection results in the cause of many diseases, such as cancer, diabetes, heart diseases, Alzheimer's, and aging [1-6].

Attarasa Litsea cubeba (Lour.) is a plant from Lauraceae family which contains much essential oils which used as antidepressant, antiinflammation, antioxidant, pesticide, antimicrobial, anticancer, and neuropharmacology [3]. Methanol extract from attarasa fruits showed to be active on cervix cancer (HeLa cell lines) which causes apoptosis through activation of caspase $3 / 7$ [3,4]. There are more than 40 isoquinoline alkaloids that contained in Litsea genus which are active as antibacterial agents against Staphylococcus aureus [5]. The heartwoods of $L$. cubeba contained a high level of phenolic and flavonoid and found to be active as antioxidant [6]. The aim of this study was to determine the antioxidant activities of alkaloids fraction of $L$. cubeba Lour. fruits.

\section{METHODS}

Plant and chemicals material

Fresh fruits of L. cubeba (Lour.) were collected from Balige subdistrict, Sumatera Utara province, Indonesia. L. cubeba (Lour.) was identified in Herbarium Medanense, Faculty of Mathematics and Natural Products, University of Sumatera Utara, and the voucher specimen was deposited in herbarium. Chemicals used were distilled water, 1,1-diphenyl-2picrylhydrazyl (DPPH) (Sigma), and methanol (Merck).

\section{Preparation of extract and fractionation}

The air-dried and powdered fruits of $L$. cubeba (Lour.) (1 kg) were repeatedly extracted by cold maceration with ethanol $96 \%(3 \times 3 d$,
$7.5 \mathrm{~L})$ at room temperature with occasional stirring. The filtrate was collected and then evaporated under reduced pressure to give a viscous extract and then freeze-dried to dry [7-9]. Viscous extract was fractionated with n-hexane and continued with chloroform at $\mathrm{pH} 3,7$, 9 , and $11[10]$.

Free radical scavenging activity test

The DPPH assay was carried out according to the previous study with some modifications [11]. About $0.2 \mathrm{mM}$ solution of DPPH• in methanol was prepared, and $100 \mu \mathrm{l}$ of this solution was added to various concentrations of fractions at the concentrations of $25,50,100$, and $200 \mu \mathrm{g} / \mathrm{ml}$. After 60 minutes, absorbance was measured at $516 \mathrm{~nm}$ and the percentage of inhibition was calculated by comparing the absorbance values of the control and test samples [2,5].

Percentage of inhibition $=\frac{\text { Abscontrol }- \text { Abstest }}{\text { Abscontrol }} \times 100 \%$

Statistical analysis

Data were expressed as mean \pm standard deviation which was analyzed using the SPSS 21 software.

\section{RESULTS AND DISCUSSIONS}

\section{Antiradical activity}

Antiradical activity of the plant was measured in terms of hydrogendonating ability using DPPH which is a stable, nitrogen-centered free radical and produces deep purple color in methanol solution, and antioxidants either transfer an electron or a hydrogen atom to DPPH, thus neutralizing its free radical character [12]. Antioxidant assay with DPPH which is based on the ability of DPPH, a stable free radical, to decolorize in the presence of antioxidants, is a direct and reliable method for determining radical scavenging action [13] and has been largely used as a quick, reliable, and reproducible at in vitro antioxidant activity assay [14]. The reducing capacity of compounds could serve as a marker of potential antioxidant activity [15-18]. Alkaloids are compound which contains $\mathrm{OH}$ and $\mathrm{NH}$ functional group, and they could be donating their hydrogen to DPPH [19]. IC ${ }_{50}$ for each fraction is shown in Table 1. 
Table 1: IC $\mathrm{I}_{50}$ value of alkaloid fractions of $L$. cubeba fruit with DPPH assay

\begin{tabular}{ll}
\hline Treatment & IC $_{\mathbf{5 0}}(\boldsymbol{\mu g} / \mathbf{m L})$ \\
\hline n-hexane Fraction & $219.43 \pm 0.43$ \\
Chloroform Fraction pH 3 & $242.97 \pm 0.93$ \\
Chloroform Fraction pH 7 & $92.38 \pm 0.17$ \\
Chloroform Fraction pH 9 & $40.84 \pm 0.04$ \\
Chloroform Fraction pH 11 & $103.83 \pm 3.29$ \\
Water Fraction & $103.75 \pm 0.42$ \\
\hline
\end{tabular}

\section{CONCLUSION}

The result of this study showed that alkaloid fractions of L. cubeba fruit possess antioxidant activity.

\section{ACKNOWLEDGMENTS}

We gratefully thank to Research Center University of Sumatera Utara through Hibah Talenta "Hibah Penelitian Dasar" Research Grant 2017 "No: 5338/UN5.1.R/PPM/2017" for financial support in the study.

\section{REFERENCES}

1. Kinnula VL, Crapo JD. Superoxide dismutases in malignant cells and human tumors. Free Radic Biol Med 2004;36:718-44.

2. Jamuna S, Pulsamy S, Karthika K. Screening of in vitro antioxidant activity of methanolic leaf and root extracts of Hypochaeris radicata $\mathrm{L}$. (Asteraceae). J App Pharm Sci 2012;2:149-54.

3. Nagmoti DM, Khatri DK, Juvekar PR, Juvekar AR. Antioxidant activity free radical-scavenging potential of Pithecellobium dulce Benth seed extracts. Free Rad Antioxid 2012;2:37-43.

4. Rackova L, Oblozinsky M, Kostalova D, Kettman V, Bezakova L. Free radical scavenging activityand lipoxygenase inhibition of Mahonia aquifolium extract and isoquinoline alkaloids. J Inflam 2007;4:15.

5. Rosidah, Yam MF, Sadikun A, Asmawi MZ. Antioxidant potential of Gyunura procumbens.Pharm Bio 2008;46:616-625.

6. Yang $\mathrm{YC}, \mathrm{Lu} \mathrm{FH}, \mathrm{Wu}$ JS, Wu $\mathrm{CH}$, Chang $\mathrm{CJ}$. The protective effect of habitual tea consumption on hypertension. Arch Intern Med 2004;164:1534-40.
7. Satria D, Furqan M, Hadisahputra S, Rosidah. Combinational effects of ethylacetate extract of Picria fel-terrae Lour. And doxorubicin on T47D breast cancer cells. Int J Pharm Pharm Sci 2015;7:73-6.

8. Anggraeni R, Hadisahputra S, Silalahi J, Satria D. Combinational effects of ethylacetate extract of Zanthoxylum acanthopodium DC. With doxorubicin on T47D breast cancer cells. Int J PharmTech Res 2014;6:2032-2035.

9. Hasibuan PAZ, Jessy C, Denny S. Combination effect of ethylacetate extracts of Plectranthus ambonicius (Lour.) spreng. With doxorubicin againts T47D breast cancer cells. Int J Pharm Pharm Sci 2015;7:155-9.

10. Atta-ur-Rahman, Atia-tul-Wahab, Sultani SZ, Nawaz SA, Choudhary MI. Bisbenzylisoquinoline alkaloids from cocculus pendulus. Nat Prod Res 2009;23:1265-73.

11. Jebitta R, Allwin J. Antioxidant activity, total phenolic, flavonoid, and anthocyanin contents of Jamun (Syzygium cumini) pulp powder. Asian J Pharm Clin Res 2016;9:361-3.

12. Pan $\mathrm{Y}$, Wang $\mathrm{K}$, Huang $\mathrm{S}$, Wang $\mathrm{H}, \mathrm{Mu} \mathrm{X}, \mathrm{He} \mathrm{C}$, et al. Antioxidant activity of microwave-assisted extract of longan (Dimocarpus longum Lour.) peel. Food Chem 2008;106:1264-70.

13. Hasan MS, Ahmed MI, Mondal S, Uddin SJ, Masud MM, Sadhu SK, et al. Antioxidant, antinociceptive activity and general toxicity study of Dendrophthoe falcata and isolation of quercitin as the major component. Opem 2006;6:355-60.

14. Koleva II, van Beek TA, Linssen JP, de Groot A, Evstatieva LN. Screening of plant extracts for antioxidant activity: A comparative study on three testing methods. Phytochem Anal 2002;13:8-17.

15. Meir S, Kanner J, Akiri B, Hada SP. Determination and involvement of aqueous reducing compounds in oxidative defense system of various senescing leaf. J Agricult Food Chem 1995;43:1813-9.

16. Dalimunthe A, Suryadi S, Satria D. Phenolic, flavonoid content and antioxidant activities of ethylacetate extract of Litsea cubeba (Lour.) pers. barks. Pharm Chem 2016;8:466-8.

17. Shah A, Singh T, Rekha V. In vitro antioxidant properties and total phenolic and flavonoid contents of Rumex vesicaius L. Int J Pharm Pharma Sci 2015;7:81-4.

18. Satria D, Silalahi J, Haro G, Ilyas S, Hsb PA. Antioxidant and antiproliferative activities of an ethylacetate fraction of Picria felterrae lour. Herbs Asian Pac J Cancer Prev 2017;18:399-403.

19. Son S, Lewis BA. Free radical scavenging and antioxidative activity of caffeic acid amide and and ester analogues: Structure activity relationship. J Agric Food Chem 2002;50:468-72. 